\title{
EVALUASI MODEL KOMUNIKASI BIDAN DESA SEBAGAI UJUNG TOMBAK UPAYA PENURUNAN ANGKA KEMATIAN IBU BERSALIN DI KABUPATEN SUKABUMI PROVINSI JAWA BARAT
}

\author{
Dedi Rumawan Erlandia, Ilham Gemiharto \\ Program Studi Manajemen Komunikasi, Fakultas Ilmu Komunikasi, Universitas Padjadjaran
}

\begin{abstract}
ABSTRAK
Angka kematian ibu adalah risiko yang terkait dengan setiap kehamilan yaitu risiko obstetrik. Hal ini dihitung sebagai jumlah kematian ibu selama tahun tertentu per 100.000 kelahiran hidup pada periode yang sama. Pada Tahun 2012, Angka Kematian Ibu Ratio (MMR) di Indonesia meningkat tajam menjadi 359 kematian per 100.000 kelahiran hidup dibandingkan dengan 228 kematian per 100.000 kelahiran hidup pada tahun 2010. Provinsi Jawa Barat merupakan penyumbang terbesar MMR tinggi di Indonesia dengan 369/100.000 kelahiran hidup pada tahun 2012 dan 238/100.000 hidup kelahiran pada tahun 2010. Sukabumi merupakan salah satu kabupaten dengan MMR tertinggi di Jawa Barat dengan sebanyak 363/100.000 kelahiran hidup pada tahun 2012 dan 226/100.000 kelahiran hidup pada tahun 2010. Sementara target MDG's untuk MMR pada tahun 2015 adalah 102/100.000 kelahiran hidup. Semua program yang diarahkan pada peran bidan desa sebagai ujung tombak upaya penurunan AKI di Indonesia. Seorang bidan dituntut untuk memiliki kemampuan komunikasi yang baik aktif, dan dinamis, dan dapat diterima oleh masyarakat karena keberhasilan program dalam menurunkan AKI di Indonesia, 73\% ditentukan oleh keahlian seorang bidan dalam melayani pasien. Seperti di kabupaten lain di Indonesia, setiap bidan di Kabupaten Sukabumi juga melayani persalinan dari satu atau dua desa di wilayah tersebut. AKI di Sukabumi menurun lebih dari $60 \%$ dibandingkan dengan angka tahun sebelumnya. Komunitas model komunikasi bidan di Kabupaten Sukabumi dianggap memiliki kontribusi penting terhadap prestasi tersebut.
\end{abstract}

Kata-kata Kunci: Model komunikasi kesehatan, bidan desa, angka kematian ibu, Kabupaten Sukabumi, Jawa Barat

\section{THE EVALUATION OF COMMUNITY MIDWIVES COMMUNICATION MODEL AS THE SPEARHEAD IN DECREASING EFFORTS OF MATERNAL MORTALITY RATE IN SUKABUMI REGENCY WEST JAVA PROVINCE}

\begin{abstract}
Maternal mortality ratio is the risk associated with each pregnancy i.e. the obstetric risk. It is calculated as the number of maternal deaths during a given year per 100,000 live births during the same period. (WHO, 2009). In the Year 2012, Maternal Mortality Ratio (MMR) in Indonesia rose sharply to 359 deaths per 100.000 live births compared to 228 deaths per 100.000 live births in 2010. West Java Province is the largest contributor to the high MMR in Indonesia with 369/100.000 live births in 2012 and 238 /100.000 live births in 2010. Sukabumi is one of the regency with the highest MMR in West Java with as many as 363/100.000 live births in 2012 and 226/100.000 live births in 2010. While The MDG's targets for MMR in 2015 was 102/100.000 live births. Various programs have been launched by the central and local governments to reduce the high MMR in Indonesia. All programs were geared towards the role of the community midwife as the spearhead of efforts to decreasing MMR in Indonesia. A midwife is required to have good active, and dynamic communication skills, and also could be accepted by the community because the program successfully decrease MMR number in Indonesia, which 73\% determined by the expertise of a midwife in serving patients. The same with other regencies in Indonesia, every midwive in Sukabumi regency also serves the maternity on one or two villages in the region. MMR in Sukabumi decreased by more than 60\% over the previous year figures. Midwive Community models of communication in Sukabumi regency is considered as an important contribution to the achievement.
\end{abstract}

Keywords: Health communication model, community midwive, maternal mortality ratio, sukabumi regency, west java

Korespondensi: Ilham Gemiharto, S.Sos., M.Si. Program Studi Manajemen Komunikasi, Fakultas Ilmu Komunikasi, Universitas Padjadjaran. Jl. Raya Bandung-Sumedang Km.21.Email: ilham265@gmail.com 


\section{PENDAHULUAN}

Masyarakat di Indonesia terutama yang tinggal di wilayah pedesaan umumnya masih sulit untuk memperoleh pelayanan kesehatan yang dapat menyediakan persalinan aman dikarenakan jarak antara tempat pelayanan persalinan dengan kediaman ibu hamil sangat jauh, selain juga kendala keuangan dan ketersediaan alat transportasi. Di samping itu masih ada kelemahan dari pihak pelayanan kesehatan sendiri yaitu kurangnya fasilitas dan jumlah petugas yang terlatih serta kurang terampilnya tenaga yang terlatih (The White Ribbon, 2003: 5-6). Selain itu masih banyak ibuibu yang menganggap kehamilan sebagai hal yang biasa, alamiah dan kodrati. Mereka merasa tidak perlu memeriksakan dirinya secara rutin ke fasilitas kesehatan baik ke bidan ataupun dokter. Masih banyaknya ibu-ibu yang kurang menyadari pentingnya pemeriksaan kehamilan, hal ini menyebabkan tidak terdeteksinya faktorfaktor resiko tinggi yang mungkin dialami oleh mereka. Resiko ini baru diketahui pada saat persalinan yang sering kali karena kasusnya sudah terlambat dapat membawa akibat fatal yaitu kematian.

Dalam Undang-Undang Nomor 36 tahun 2009 tentang Kesehatan, pada pasal 5 ayat (1) menegaskan bahwa setiap orang mempunyai hak yang sama dalam memperoleh akses atas sumber daya di bidang kesehatan. Selanjutnya pada ayat (2) ditegaskan bahwa setiap orang mempunyai hak dalam memperoleh pelayanan kesehatan yang aman, bermutu, dan terjangkau. Kemudian pada ayat (3) bahwa setiap orang berhak secara mandiri dan bertanggung jawab menentukan sendiri pelayanan kesehatan yang diperlukan bagi dirinya. Selanjutnya pada pasal 6 ditegaskan bahwa setiap orang berhak mendapatkan lingkungan yang sehat bagi pencapaian derajat kesehatan. Untuk menjamin terpenuhinya hak hidup sehat bagi seluruh penduduk termasuk penduduk miskin dan tidak mampu, pemerintah bertanggung jawab atas ketersediaan sumber daya di bidang kesehatan yang adil dan merata bagi seluruh masyarakat untuk memperoleh derajat kesehatan yang setinggi-tingginya.

Komunikasi memiliki peran penting dalam setiap tindakan yang bertujuan untuk meningkatkan kesehatan. Sulit untuk membayangkan bagaimana sebuah pesan dapat disampaikan untuk mempromosikan pilihan yang sehat jika kita tidak bisa berkomunikasi. Proses komunikasi adalah transaksi multidimensi yang dipengaruhi oleh berbagai faktor. Dalam komunikasi kesehatan keberhasilan pertukaran informasi antara praktisi dan audiens sasaran merupakan hal yang menjadi perhatian utama. (Corcoran, 2007:5).

Komunikasi dalam kesehatan dapat didefinisikan dengan cara yang sama seperti halnya komunikasi secara umum didefinisikan yaitu sebagai suatu proses transaksional. Perbedaan utama dalam komunikasi kesehatan adalah bahwa fokusnya mengenai informasi kesehatan. Penambahan 'kesehatan' dengan definisi komunikasi sebagai 'sumber' yang memungkinkan pesan kesehatan (misalnya pencegahan, risiko atau kesadaran) untuk digunakan dalam pendidikan dan mencegah terjadinya penyakit. (Kreps: 2003)

Angka kematian ibu adalah risiko yang terkait dengan setiap kehamilan yaitu risiko obstetrik. Hal ini didapatkan dengan menghitung jumlah kematian ibu selama tahun tertentu per 100.000 kelahiran hidup pada periode yang sama. (WHO, 2009). Pada Tahun 2012, Angka Kematian Ibu (AKI) di Indonesia meningkat tajam menjadi 359 kematian per 100.000 kelahiran hidup dibandingkan dengan 228 kematian per 100.000 kelahiran hidup pada tahun 2010. Provinsi Jawa Barat merupakan penyumbang terbesar tingginya AKI di Indonesia dengan 369/100.000 kelahiran hidup pada tahun 2012 dan 238 / 100.000 hidup kelahiran pada tahun 2010. Sukabumi merupakan salah satu kabupaten dengan AKI tertinggi di Jawa Barat yaitu sebanyak 363/100.000 kelahiran hidup pada tahun 2012 dan 226/100.000 kelahiran hidup pada tahun 2010. Sementara target MDG 's untuk AKI pada tahun 2015 adalah 102/100.000 kelahiran hidup.

Berbagai program telah diluncurkan oleh pemerintah pusat dan daerah untuk mengurangi tingginya AKI di Indonesia. Semua program diarahkan pada peran bidan desa sebagai ujung tombak upaya penurunan AKI di Indonesia. Seorang bidan dituntut untuk memiliki kemampuan komunikasi yang baik. aktif, dan dinamis, sehingga dapat diterima oleh masyarakat karena keberhasilan program penurunan AKI di Indonesia, 73\% ditentukan oleh keahlian seorang bidan dalam melayani pasien. 
Seperti di kabupaten lain di Indonesia, setiap bidan di Kabupaten Sukabumi juga melayani persalinan dari satu atau dua desa di wilayah tersebut. Pada 2013, AKI di Sukabumi menurun lebih dari $60 \%$ dibandingkan dengan angka tahun sebelumnya. Komunitas model komunikasi bidan di Kabupaten Sukabumi dianggap memiliki kontribusi penting terhadap prestasi tersebut.

Berdasarkan latar belakang masalah, maka terdapat masalah penelitian yang dituangkan dalam dua rumusan masalah yaitu, Pertama, bagaimana Model Komunikasi Bidan Desa dalam Upaya Penurunan Angka Kematian Ibu Bersalin di Kabupaten Sukabumi Propinsi Jawa Barat, dan Kedua, faktor-faktor apakah yang mendukung Model Komunikasi Bidan Desa dalam Upaya Penurunan Angka Kematian Ibu Bersalin di Kabupaten Sukabumi Propinsi Jawa Barat.

Penelitian ini memiliki dua tujuan yang ingin dicapai, yaitu, Pertama, untuk mengetahui Model Komunikasi Bidan Desa dalam Upaya Penurunan Angka Kematian Ibu Bersalin di Kabupaten Sukabumi Propinsi Jawa Barat, dan Kedua, untuk mengetahui faktor-faktor yang mendukung Model Komunikasi Bidan Desa dalam Upaya Penurunan Angka Kematian Ibu Bersalin di Kabupaten Sukabumi Propinsi Jawa Barat.

\section{METODE PENELITIAN}

Penelitian ini menggunakan metode kualitatif. Penelitian ini mengenai evaluasi model bidan desa dalam menurunkan AKI di Kabupaten Sukabumi, Provinsi Jawa Barat. Metode analisis penelitian ini yang digunakan adalah analisis studi kasus berdasarkan metode, data, dan triangulasi sumber. Sedangkan metode pengumpulan data dalam penelitian ini adalah melalui penelitian kepustakaan dan penelitian lapangan berupa obsevasi dan wawancara mendalam yang dilaksanakan mulai Agustus hingga Oktober 2014. Data yang dikumpulkan dalam penelitian ini terbagi menjadi data primer dan data sekunder. Data primer merupakan hasil observasi dan wawancara mendalam dengan 6 (enam) informan penelitian di lokasi penelitian, sementara data sekunder adalah data yang diperoleh dari situs-situs berita online (website), jurnal-jurnal komunikasi, serta buku-buku yang relevan dengan penelitian ini.
Teknik analisis data yang digunakan dalam penelitian ini adalah mengacu pada konsep Milles \& Huberman (1992: 20) yaitu interactive model yang mengklasifikasikan analisis data dalam tiga langkah, yaitu :

\section{Reduksi data (Data Reduction)}

Reduksi data yaitu suatu proses pemilahan, pemusatan perhatian pada penyederhanaan, pengabstrakan dan transformasi data kasar yang muncul dari catatan-catatan tertulis di lapangan.

\section{Penyajian data (Display Data)}

Data ini tersusun sedemikian rupa sehingga memberikan kemungkinan adanya penarikan kesimpulan dan pengambilan tindakan. Adapun bentuk yang lazim digunakan pada data kualitatif terdahulu adalah dalam bentuk teks naratif.

\section{Penarikan kesimpulan (Verifikasi)}

Dalam penelitian ini akan diungkap mengenai makna dari data yang dikumpulkan. Dari data tersebut akan diperoleh kesimpulan yang tentatif, kabur, kaku dan meragukan, sehingga kesimpulan tersebut perlu diverifikasi. Verifikasi dilakukan dengan melihat kembali reduksi data maupun display data sehingga kesimpulan yang diambil tidak menyimpang.

Teknik uji keabsahan lain yang digunakan oleh peneliti adalah perpanjangan keikutsertaan. Menurut Moleong (2007: 327) perpanjangan keikutsertaan berarti peneliti tinggal di lapangan penelitian sampai kejenuhan pengumpulan data tercapai. Dalam hal ini, peneliti memperpanjang atau menambah waktu wawancara dan observasi terhadap kedua subjek agar data mencapai kejenuhan.

\section{HASIL DAN PEMBAHASAN}

\section{Angka Kematian Ibu Melahirkan di Kabupaten Sukabumi}

Menurut SDKI 2012, terdapat lima propinsi sebagai penyumbang terbesar AKI di Indonesia, dengan total angka 5.767 kematian atau 50\% dari 11.767 kematian ibu di Indonesia tahun 2010. Lima propinsi tersebut secara 
berturut-turut adalah Jawa Barat, Jawa Tengah, Nusa Tenggara Timur, Banten dan Jawa Timur. Apabila di lima propinsi tersebut AKI dapat diturunkan secara signifikan, maka akan berpengaruh besar terhadap penurunan angka kematian ibu secara nasional. (Kemenkes, 2012)

Kasus kematian ibu di Jawa Barat tahun 2009 - 2012 berturut turut adalah sebanyak 828, 804, 850 dan 781 kasus. Sedangkan kasus kematian bayi berturut-turut adalah sebanyak 5.719, 4.982, 5.070 dan 4.650 kasus. Data Dinas Kesehatan Provinsi Jawa Barat ini menunjukkan tren yang turun naik namun hingga saat ini kasus kematian ibu dan bayi di Jawa Barat masih yang tertinggi di Indonesia.

AKB di Kabupaten Sukabumi pada tahun 2005 adalah 53,25 per 1000 kelahiran hidup dan 45 per 1.000 kelahiran hidup pada tahun 2009 . Sedangkan AKI pada tahun 2005 dan pada tahun 2010 masing masing 363 dan 226 per 100.000 angka kelahiran hidup.

Ada fenomenamenarik setelah diberlakukan kebijakan Jampersal di Kabupaten Sukabumi sejak tahun 2011. Jumlah kasus kematian bayi dan ibu sejak 2010 hingga 2012 menunjukan trend yang meningkat, jumlah kasus kematian bayi pada 2010 sebanyak 228 kasus, kemudian pada 2011 naik menjadi 358 kasus, pada 2012 naik menjadi 479. Berdasarkan data Dinas Kesehatan Provinsi Jawa Barat Tahun 2013, angka tahun 2012 merupakan yang tertinggi di jawa Barat dari total kasus kematian bayi di Jawa Barat sebanyak 4.650 kasus.

Demikian juga kasus kematian ibu terjadi kenaikan sejak 2010 hingga 2012 yaitu pada 2010 sebanyak 40 kasus, pada 201170 kasus, dan pada 2012 sebanyak 76 kasus, jumlah kasus kematian ibu di Kabupaten Sukabumi pada tahun 2012 juga merupakan yang terbanyak diantara Kabupaten Kota di Jawa Barat. Total kasus kematian ibu di Jawa Barat adalah 781 kasus dan 76 diantaranya terjadi di Kabupaten Sukabumi.

Salah satu faktor penyebab tingginya AKI berhubungan dengan pemilihan pertolongan persalinan, dan tidak semua ibu hamil melakukan proses persalinan di sarana kesehatan atau menggunakan pertolongan Tenaga Kesehatan. (Profil Kesehatan Indonesia, 2007). Selain itu kesulitan akses terhadap pelayanan kesehatan juga menyebabkan rendahnya pemanfaatan pelayanan kesehatan. Selain akses jarak, akses biaya juga mempengaruhi, sehingga masyarakat masih banyak yang beranggapan bahwa bila persalinan ditolong oleh bidan biayanya mahal sedangkan bila ditolong oleh dukun bisa membayar berapa saja. (Anggorodi, Rina, 2009).

Kondisi sosial ekonomi \& pengetahuan mempengaruhi preferensi ibu hamil untuk melakukan proses persalinan menggunakan dukun beranak. Hal ini menuntut adanya strategi dalam memberikan intervensi medis mengingat determinan dari angka kematian ibu bersifat kompleks. (Setyawati, Gita dan Alam, Meridian, 2010). Disparitas kesehatan ibu dan anak antara lain disebabkan oleh faktor geografis - daerah terpencil dan kepulauan, belum terpenuhinya kebutuhan masyarakat akan ketersediaan fasilitas pelayanan kesehatan dan obat-obatan yang terjangkau, kurangnya tenaga kesehatan, serta masih adanya hambatan finansial masyarakat dalam mengakses pelayanan kesehatan yang disediakan oleh Pemerintah. (Kemenkes, 2012).

\section{Kebijakan Bidang Kesehatan Pemerintah Daerah Kabupaten Sukabumi}

Pemerintah telah melaksanakan penjaminan pelayanan kesehatan terhadap masyarakat miskin dan tidak mampu sejak tahun 2005 dengan nama ASKESKIN yang kemudian di tahun 2008 berganti nama menjadi JAMKESMAS. Biaya pelayanan tersebut sangat bermanfaat dan dirasakan langsung oleh masyarakat miskin. Tahun 2008 pemerintah menerbitkan kartu Jaminan Kesehatan Masyarakat (Jamkesmas) yang merupakan Jaminan Pelayanan Kesehatan bagi masyarakat miskin dengan sumber biaya dari pusat.

Jaminan Persalinan (Jampersal) adalah perluasan kepesertaan dari jamkesmas dan tidak hanya mencakup dari masyarakat miskin saja. Manfaat yang di terima oleh penerima adalah manfaat jaminan persalinan terbatas pada pelayanan kehamilan, persalinan, nifas, bayi baru lahir dan KB pasca salin. Baik Jamkesmas maupun Program Jampersal dilaksanakan pemerintah dalam rangka mencapai tujuan Pembangunan Kesehatan Nasional serta global yang tertuang dalam Millenium Development Goals (MDGs).

Khusus mengenai Program Jampersal yang dilaksanakan di Kabupaten Sukabumi karena Angka Kematian Ibu (AKI) dan Angka Kematian 


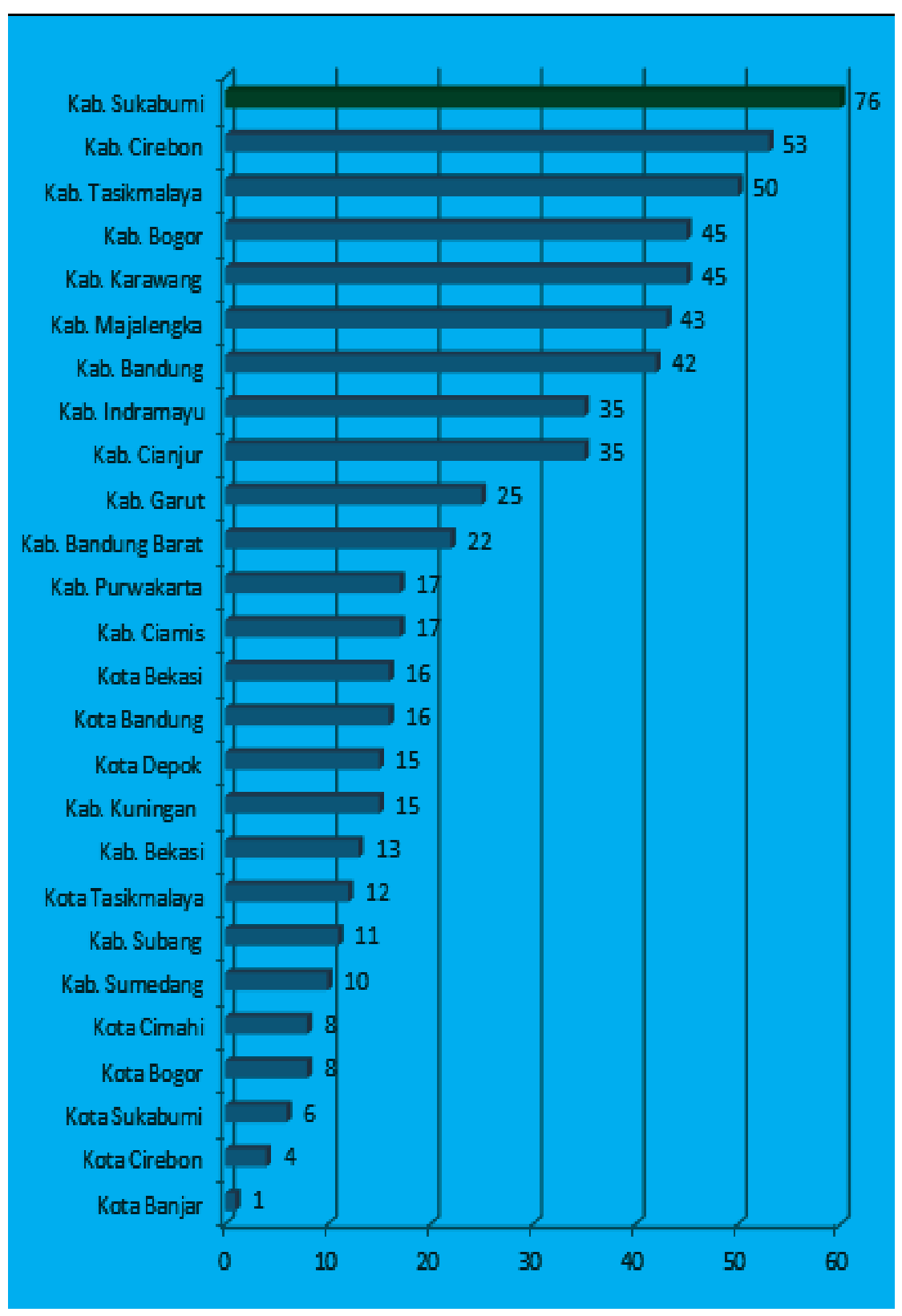

\section{Diagram 1. Angka Kematian Ibu di Kabupaten Sukabumi Tahun 2012}

Sumber : Dinas Kesehatan Kabupaten Sukabumi 2012

Bayi (AKB) pada tahun 2012 terbilang masih cukup tinggi dibandingkan dengan kabupaten/ kota lainnya di Indonesia. Adapun jumlah kematian ibu karena melahirkan dapat dilihat pada diagram 1.

Dari diagram 1 terlihat bahwa AKI di Kabupaten Sukabumi pada tahun 2012 adalah yang tertinggi dibandingkan kabupaten/kota lainnya di Indonesia. Sedangkan faktor-faktor penyebab kematian ibu pada saat melahirkan di Kabupaten Sukabumi tersebut sebagaimana terlihat pada diagram 2 .
Sedangkan untuk data tahun 2013 tentang gambaran ibu hamil di Kabupaten Sukabumi dapat dilihat pada tabel 1 .

Berdasarkan data pada tabel diatas jumlah persalinan ibu hamil yang ditangani oleh tenaga kesehatan $(55,1 \%)$ masih lebih besar daripada jumlah persalinan ibu hamil yang ditangani oleh dukun/paraji. Data diatas sudah menunjukkan gambaran yang baik mengenai kondisi pelayanan kesehatan bagi ibu-ibu hamil dan melahirkan.

Wilayah Kabupaten Sukabumi terbilang sangat luas yang dibagi secara administratif 
Tabel 1 Jumlah Ibu Hamil dan Pertolongan Persalinan

\begin{tabular}{cll}
\hline No & \multicolumn{1}{c}{ Kategori } & \multicolumn{1}{c}{ Jumlah } \\
\hline 1 & Estimasi Ibu Hamil & 59.872 \\
2 & Estimasi ibu bersalin & 57.150 \\
3 & Jumlah Ibu Hamil s.d. Agustus & 39.891 \\
4 & Ibu Hamil terdeteksi resiko tinggi & 11.508 (30\% dari jumlah ibu hamil) \\
5 & Data Persalinan & \\
& $-\quad$ Ditolong tenaga kesehatan (nakes) & 31.495 atau 55,1\% dari target sasaran \\
& $-\quad$ Ditolong dukun/paraji & 1.447 atau 2,5\% dari target sasaran \\
& $-\quad$ Lolos & 129 atau $0,2 \%$ akibat KTD/Masalah \\
\end{tabular}

Sumber: Dinas Kesehatan Kabupaten Sukabumi 2012

sebanyak 47 kecamatan. Dari sejumlah kecamatan-kecamatan tersebut data ibu hamil yang beresiko tinggi yang berhasil dideteksi oleh tenaga kesehatan dan masyarakat tahun 2013 per kecamatan dibagi dalam beberapa diagram.

Data pada tabel hanya menunjukkan data ibu hamil yang terdeteksi beresiko tinggi dari 11 kecamatan yaitu Cikembar hingga Sukalarang. Sedangkan data ibu hamil resti dari kecamatan lainnya dapat dilihat pada tabel.

Berikut jumlah ibu hamil resti di kecamatan lainnya (Caringin hingga Surade).
Terakhir, data ibu hamil beresiko tinggi di Kabupaten Sukabumi Tahun 2013 per kecamatan dapat dilihat pada diagram 7 .

Data perkiraan ibu hamil maupun ibu hamil dengan resiko tinggi tersebut, maka dengan adanya Program Jampersal diharapkan dapat membatu pertolongan pada persalinan ibu hamil terutama bagi sebagian besar masyarakat miskin di Kabupaten Sukabumi.

Jumlah masyarakat miskin di Kabupaten Sukabumi terbilang masih cukup banyak yang masih membutuhkan Jaminan Pelayanan Kesehatan. Berdasarkan Surat Keputusan

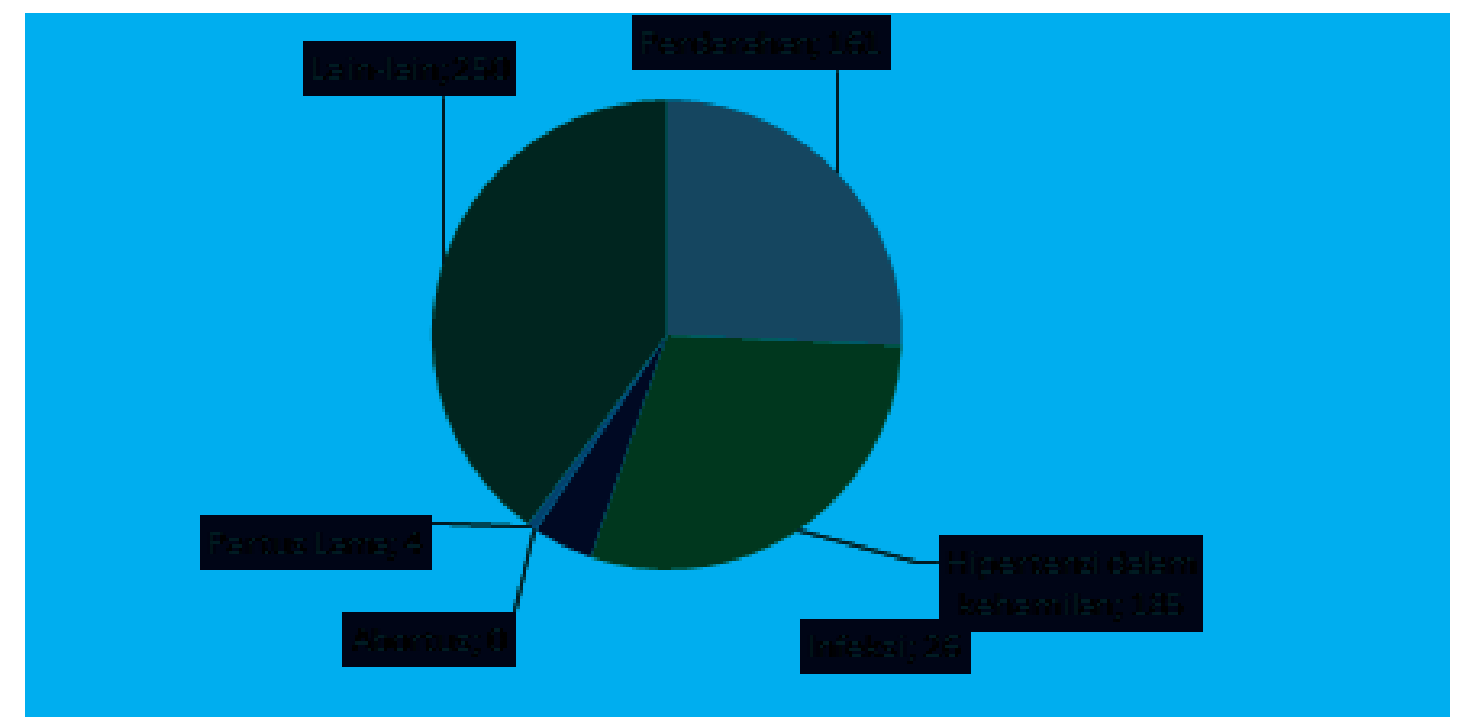

Diagram 2 Faktor-Faktor Penyebab Kematian Ibu pada Saat Melahirkan di Kabupaten Sukabumi Tahun 2012

Sumber: Dinas Kesehatan Kabupaten Sukabumi 2012 


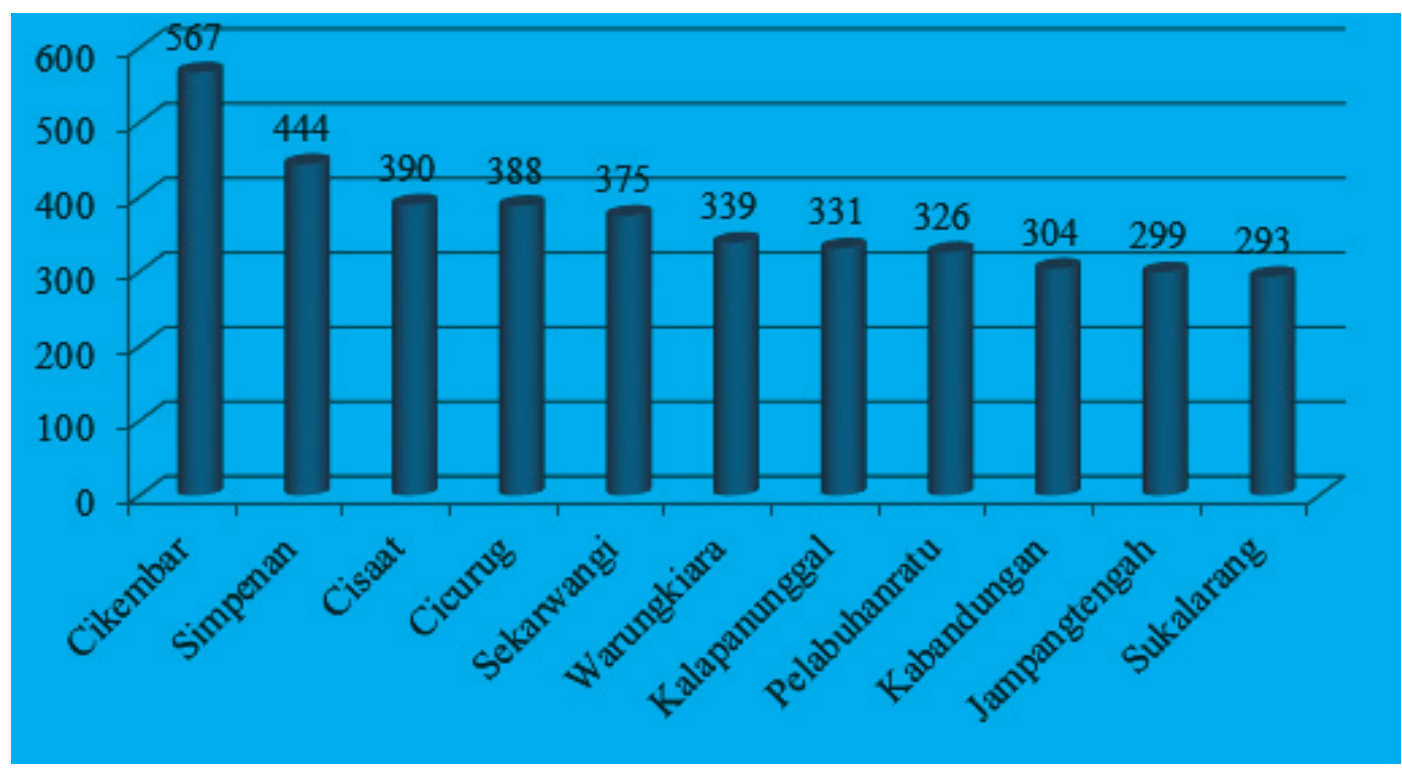

Diagram 3 Jumlah Ibu Hamil Beresiko Tinggi per Kecamatan Tahun 2013 (1)

Sumber : Dinas Kesehatan Kabupaten Sukabumi 2013

Bupati Sukabumi Nomor: 470/Kep. 452- jiwa.

KBPP/2011 Tentang Penetapan Data Keluarga

Dan Individu Anggota Keluarga Miskin

Berdasarkan Tahapan Keluarga Sejahtera

Pra-Sejahtera Alasan Ekonomi Dan Keluarga

Sejahtera I Alasan Ekonomi Kabupaten

Sukabumi Tahun 2012 sebanyak 1.082.127

Dari jumlah masyarakat miskin tersebut, sebanyak 820.804 jiwa telah di jamin kesehatannya oleh pusat, sehingga sisanya yaitu sebanyak 261.323 jiwa menjadi tanggung jawab pemerintah daerah Kabupaten Sukabumi. Adapun dana yang dialokasikan dari Anggaran

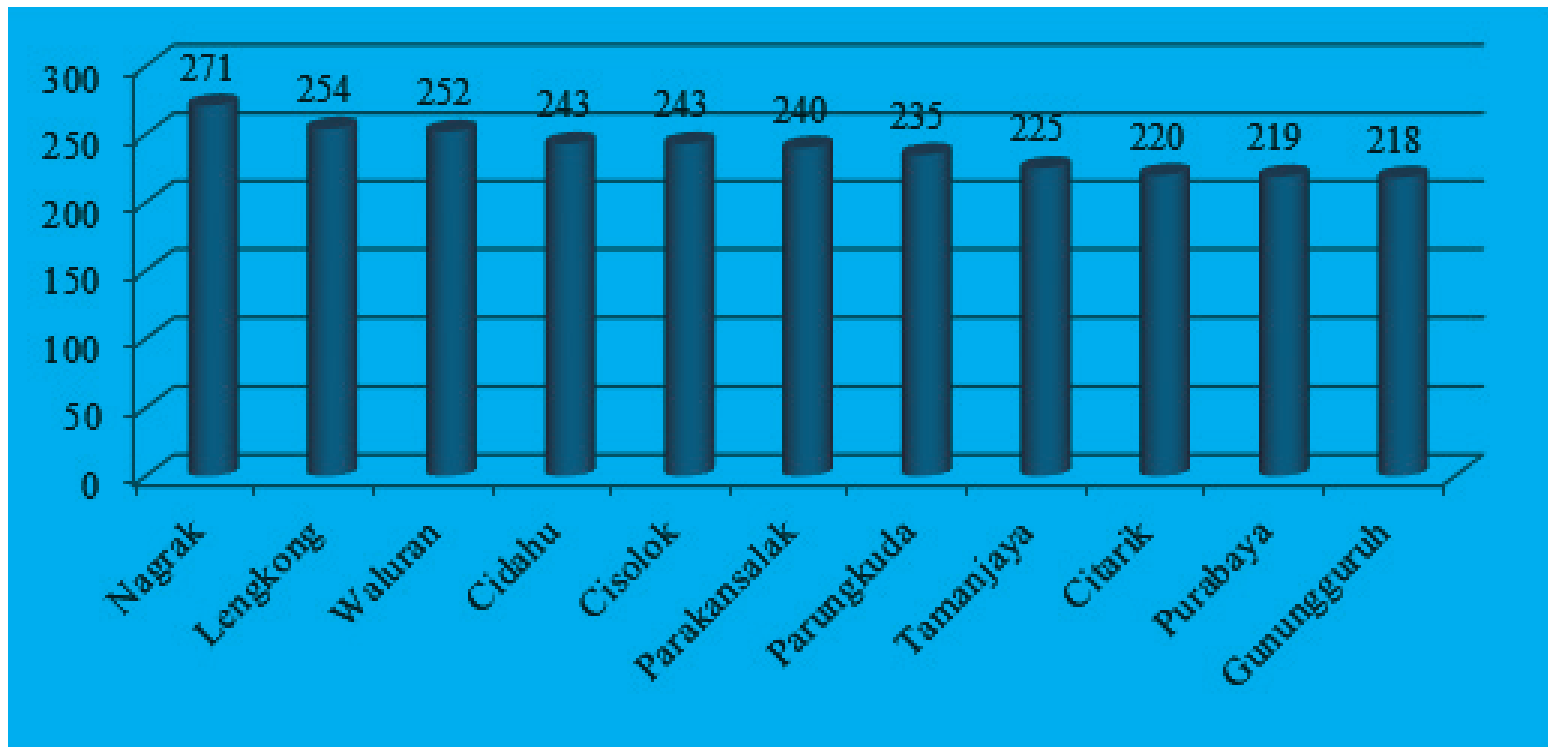

Diagram 4 Jumlah Ibu Hamil Beresiko Tinggi per Kecamatan Tahun 2013 (2)

Sumber: Dinas Kesehatan Kabupaten Sukabumi, 2013 


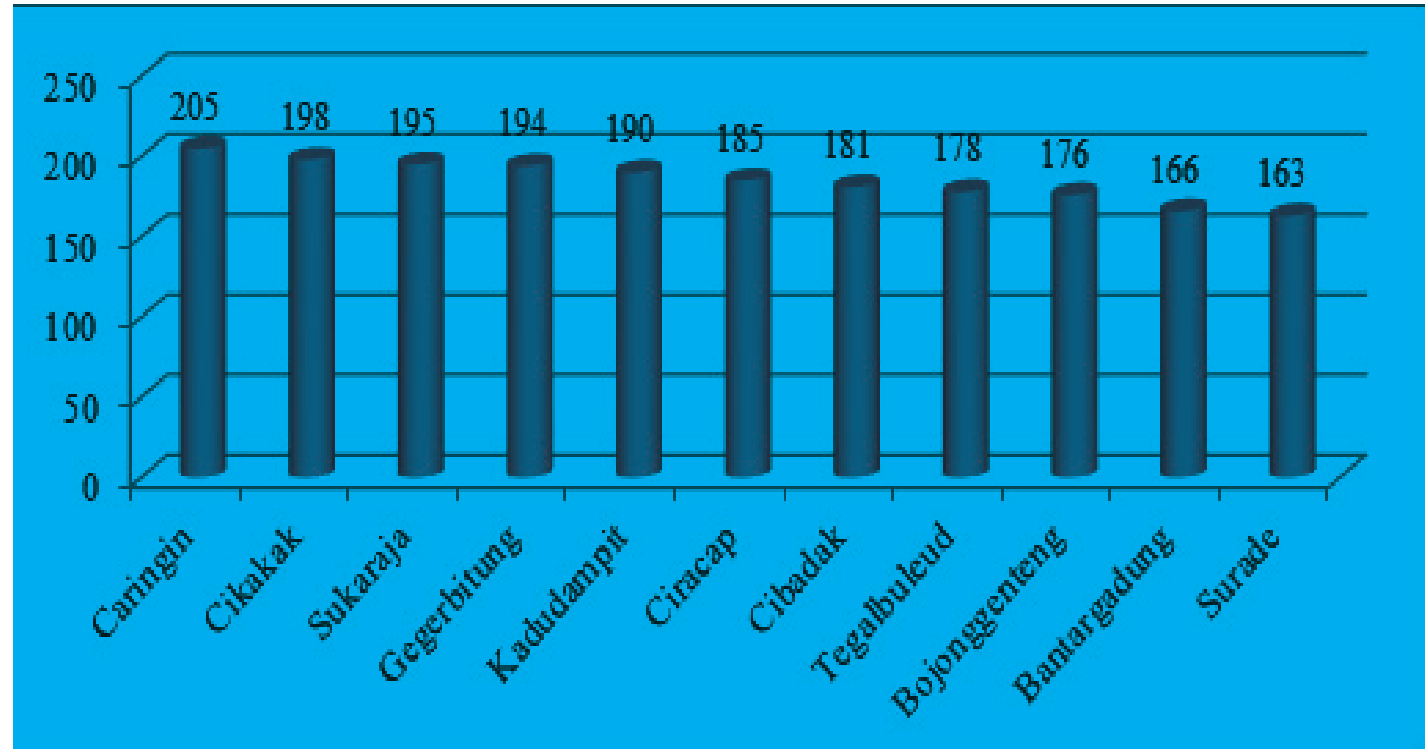

Diagram 5 Jumlah Ibu Hamil Beresiko Tinggi per Kecamatan Tahun 2013 (3)

Sumber: Dinas Kesehatan Kabupaten Sukabumi, 2013

Pemerintah untuk Jamkesmas dan Jampersal sebagai berikut:

Luncuran pertama Bulan April : 7.889.626.523,Luncuran Kedua Bulan Juli : : 10.518.241.000,Luncuran Ketiga Bulan Nov : 7.888 .681 .000 ,Jumlah : 26.296.548.523,-

\section{Peran Bidan Desa}

Fungsi dan peran bidan desa dalam upaya peningkatan kualitas kesehatan masyarakat sangat penting, namun tanpa dukungan, kerjasama dan peran aktif masyarakat, upaya tersebut tidak akan maksimal.

Bidan memiliki peran sebagai sebagai pelaksana dalam pelayanan asuhan kebidanan kepada ibu hamil selama kehamilan, persalinan, dan masa nifas, kemudian pada bayi baru lahir, PUS (pasangan usia subur), pelayanan Keluarga Berencana, wanita dengan gangguan reproduksi dan menopause. Bidan berperan pula sebagai pengelola pelayanan dasar kesehatan terutama untuk pelayanan individu, keluarga, dan masyarakat. Bidan juga memiliki peran dalam

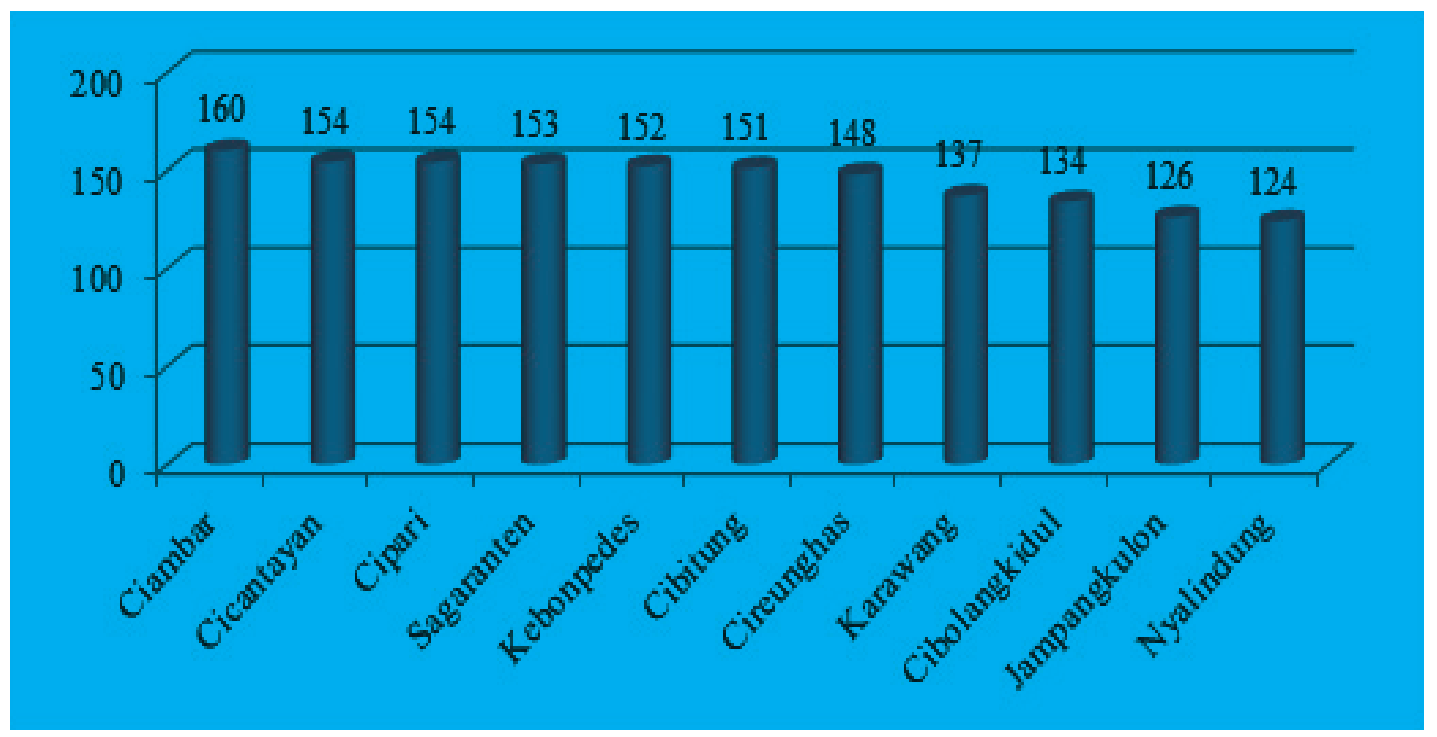

Diagram 6 Jumlah Ibu Hamil Beresiko Tinggi per Kecamatan Tahun 2013 (1) Sumber : Dinas Kesehatan Kabupaten Sukabumi 2013 


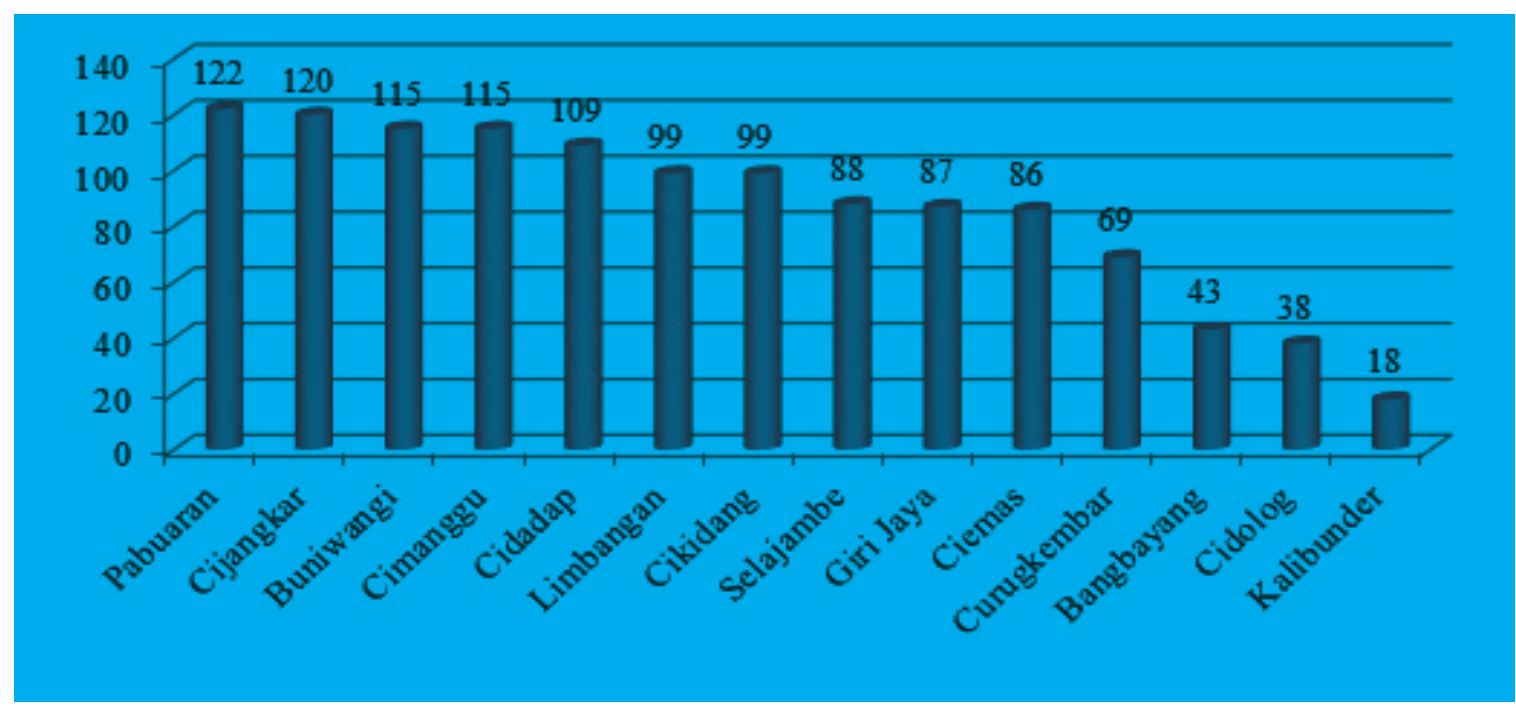

Diagram 7 Jumlah Ibu Hamil Beresiko Tinggi per Kecamatan Tahun 2013 (1)

Sumber : Dinas Kesehatan Kabupaten Sukabumi 2013

mengelola program kesehatan di wilayah kerjanya.

Peran bidan selanjutnya adalah memberikan pendidikan dan penyuluhan kesehatan tentang penanggulangan masalah kesehatan khususnya yang berhubungan dengan Kesehatan Ibu, Anak dan KB. Bidan juga memiliki peran dalam melaksanakan investigasi atau penelitian terapan dalam bidang kesehatan baik secara mandiri maupun kelompok di wilayah kerjanya.

\section{Strategi Pelayanan Program Bidan Desa}

Strategi pelayanan program bidan desa didasarkan kepada 3 (tiga) pendekatan. Pertama, pendekatan edukatif dalam peran serta masyarakat. Pelayanan bidan desa dikembangkan berawal dari pola hidup masyarakat desa yang tidak lepas dari faktor lingkungan, adat istiadat, ekonomi, sosial budaya, dan lain-lain.

Kedua, pelayanan yang berorientasi pada kebutuhan masyarakat, dimana masyarakat dapat mengidentifikasi kebutuhan dan menentukan skala prioritas dari hasil identifikasi kebutuhan tersebut. Selanjutnya masyarakat menentukan langkah-langkah bersama yang perlu diambil untuk memenuhi kebutuhan tersebut dengan memanfaatkan potensi kearifan lokal yang ada.

Ketiga, menggunakan atau memanfaatkan fasilitas dan potensi yang ada di masyarakat, karena masalah kesehatan pada umumnya disebabkanrendahnyastatussosial-ekonomiyang diakibatkan ketidaktahuan dan ketidakmampuan memelihara diri sendiri (self care) sehingga apabila berlangsung terus akan berdampak pada status kesehatan keluarga dan masyarakat juga produktifitasnya. Pelaksanaannya adalah dengan membantu manusia mengubah sikapnya terhadap masyarakat, membantu menumbuhkan kemampuan orang, berkomunikasi dan menguasai lingkungan fisiknya yang bertujuan mengembangkan potensi dan kemampuan manusia dalam mengontrol lingkungannya.

\section{Model Komunikasi Kesehatan Bidan Desa di Kabupaten Sukabumi}

Dengan mengacu kepada 3 langkah Strategi Pelaksanaan Program Bidan Desa yang dapat diaplikasikan model komunikasi kesehatan tertentu dalam melaksanakan tugasnya. Salah satu model yang popular digunakan dalam komunikasi kesehatan adalah model transtheoretical (TTM), yaitu model sirkular yang dikembangkan oleh Prochaska dan Di Clemente (1983). Model ini terdiri multi tahap dengan tujuan untuk mencegah orang untuk kambuh atau meninggalkan perubahan dan kembali kepada perilakunya semula.

Bidan Desa di Sukabumi memiliki tugas untuk mendorong orang untuk berpindah dari precontemplation (tidak siap untuk mengubah) ke kontemplasi (pemikiran perubahan), persiapan (bersiap-siap untuk berubah), tindakan (melakukan perubahan), 


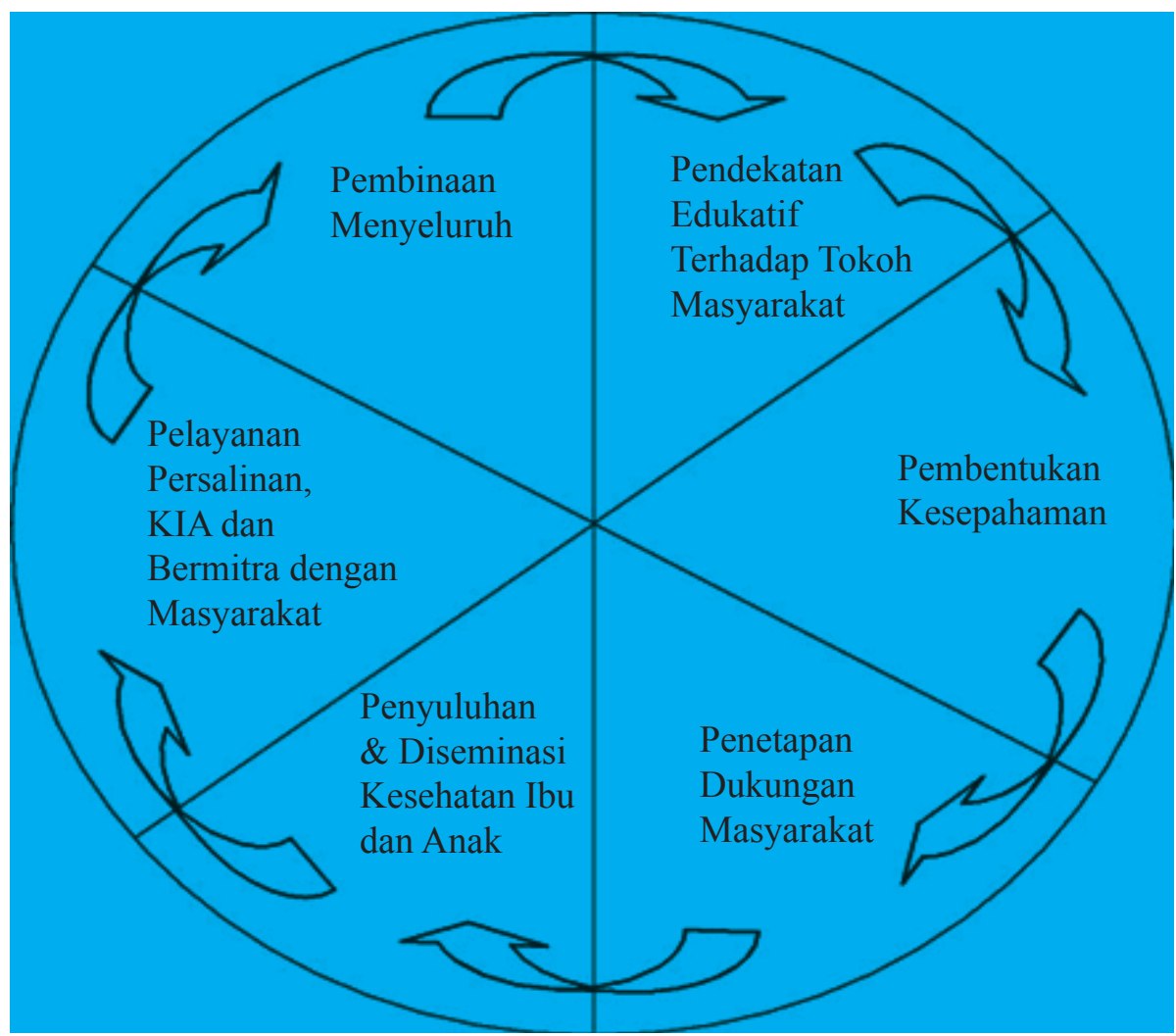

Gambar 8 Transtheoretical Communication Model, Prochaska \& Diclemente (1983)

dan pemeliharaan (melanjutkan berubah), dan mencegah masyarakat untuk tidak kambuh (meninggalkan perubahan dan kembali kepada mantan perilaku), dan terus melanjutkan perubahan.

Dengan mengadopsi model komunikasi kesehatan transtheoretical (TTM), yaitu model sirkular yang dikembangkan oleh Prochaska dan Di Clemente (1983), Bidan Desa di Kabupaten Sukabumi menggunakan model.

Dari model Komunikasi Kesehatan Transtheoretical (TTM) yang diadopsi oleh Bidan Desa di Kabupaten Sukabumi dapat dijelaskan sebagai berikut ini. Tahap Pertama, Pendekatan Edukatif kepada Tokoh Masyarakat melalui berbagai Forum yang ada, seperti acara pengajian, minggon desa, forum desa sehat, forum rakor desa bersama tokoh-tokoh agama, sesepuh desa, tokoh pemuda, dan tokoh perempuan.

Tahap Kedua, yaitu Pembentukan Kesepahaman bertujuan untuk mendapatkan dukungan dari semua pihak, khususnya tokohtokoh masyarakat dalam masyarakat terhadap program Kesehatan Ibu dan Anak, baik dukungan moral, teknis maupun individu. Tahap Ketiga, adalah Penetapan Dukungan Masyarakat baik dari tokoh-tokoh informal maupun pejabat pemerintahan melalui kemitraan dan MOU yang dilandasi kepedulian bersama terhadap peningkatan kualitas kesehatan masyarakat.

Tahap Keempat, yaitu melaksanakan tahapan Penyuluhan dan Diseminasi Kesehatan Ibu dan Anak kepada individu melalui kunjungan rutin ke rumah-rumah sasaran, melaksanakan Penyuluhan dan Diseminasi Kesehatan Ibu dan Anak kepada kelompok masyarakat dengan memanfaatkan forum-forum sosial seperti pengajian, arisan $\mathrm{PKK}$, pertemuan $\mathrm{BKB}$ dan BKL, dan Taman Posyandu, melaksanakan tahapan penyuluhan dan diseminasi kesehatan ibu dan anak secara massal dengan memanfaatkan media tradisional, acara hiburan rakyat, peringatan hari besar nasional dan acara kunjungan, dan memberikan konseling kepada Ibu Hamil, Ibu Nifas, Ibu Balita, dan Calon Ibu.

Tahap Kelima adalah memberikan pelayanan Kesehatan Ibu dan Anak (KIA) berupa Pemeriksaan Kehamilan, Persalinan, Masa Nifas dan Imunisasi bekerjasama dengan 
tenaga medis seperti Petugas Lapangan Keluarga Berencana untuk penyediaan alat kontrasepsi Keluarga Berencana, dokter Puskesmas, Rumah Bersalin Swasta dan Rumah Sakit Umum Daerah maupun Swasta.

Tahap Keenam, adalah melakukan pembinaan menyeluruh mengenai kesehatan reproduksi baik kepada individu, kelompok atau secara massal, melalui forum-forum yang ada, melakukan evaluasi proses pelaksanaan kegiatan dengan cara mencatat hal-hal yang perlu diperhatikan dan ditindaklanjuti, dan melakukan pencatatan dan pelaporan sesuai dengan kenyataan dan waktu yang telah ditentukan.

Lokasi penelitian ini mengambil lokasi di 3 (tiga) kecamatan di Kabupaten Sukabumi, yaitu kecamatan Cikembar di wilayah Utara, Kecamatan Surade di wilayah Tengah dan kecamatan Palabuhan Ratu di wilayah Selatan. Di setiap kecamatan yang menjadi lokasi penelitian, tim peneliti mewawancarai 2 (dua) orang Bidan Desa. Selain Bidan Desa di masing-masing kecamatan, tim peneliti juga mewawancarai seorang tokoh masyarakat atau pejabat terkait di masing-masing kecamatan, yaitu Camat atau Kepala Puskesmas setempat. Sehingga dalam penelitian ini terdapat 9 (sembilan) informan penelitian, yang terdiri dari 6 (enam) orang Bidan Desa dan 3 (tiga) informan dari kalangan tokoh masyarakat yaitu 1 (satu) orang Camat dan 2 (dua) kepala Puskesmas. Untuk melaksanakan tahapan Triangulasi tim peneliti mewawancarai Bupati Kabupaten Sukabumi selaku Kepala Daerah Kabupaten Sukabumi dan Ketua Ikatan Bidan Indonesia (IBI) Kabupaten Sukabumi.

Dari gambaran hasil penelitian di atas dapat diambil beberapa hal menarik dalam penerapan model komunikasi kesehatan TTM oleh Bidan Desa di Kabupaten Sukabumi. Pertama, dalam Pendekatan Edukatif kepada Tokoh Masyarakat diperlukan pendekatan yang berbeda khususnya terhadap tokoh agama (pemuka agama Islam, kyai atau ajengan) yaitu jangan sampai menyinggung perasaan mereka. Para pemuka agama tersebut ternyata lebih mendengar ucapan dari bidan yang lebih senior atau usianya sama bahkan diatas mereka. Apabila melakukan pendekatan bersama dengan bidan senior prosesnya lebih mudah karena lebih dihormati, dan seorang bidan senior mempunyai kemampuan komunikasi persuasif yang mumpuni berdasarkan pengalaman selama puluhan tahun tinggal di desa tersebut. Sementara itu di kecamatan lain dengan penduduk yang lebih heterogen dan banyak pabrik garmen, meskipun masih ada namun peran tokoh dalam masyarakat sudah jauh berkurang, karena yang lebih berperan adalah tokoh-tokoh formal seperti ketua RT, ketua RW, kepala dusun, kepala desa dan camat. Oleh karena itu pendekatan edukatif lebih diarahkan kepada mereka. Dari kedua kondisi tersebut, pendekatan edukatif kepada tokoh masyarakat harus dilakukan terutama di daerah perdesaan (rural) karena dimana masyarakat masih homogen sistem ketokohan masih berlaku, sementara di daerah urban atau perkotaan dengan penduduk yang heterogen, sistem ketokohan dalam masyarakat sudah mulai berkurang. Karena itulah diperlukan pendekatan edukatif yang berbeda di kedua kawasan tersebut.

Kedua, dalam tahap kedua model komunikasi TTM, Bidan Desa melakukan pembentukan kesepahaman dengan tokohtokoh masyarakat baik formal maupun informal. Pembentukan Kesepahaman bertujuan untuk mendapatkan dukungan dari semua pihak, khususnya tokoh-tokoh masyarakat terhadap program Kesehatan Ibu dan Anak, baik dukungan moral, teknis maupun individu. Menurut salah seorang bidan kuncinya adalah dengan cara menunjukkan niat baik dan kepedulian kita kepada kondisi kesehatan para ibu dan anak balita. Bidan Desa harus berusaha membuat para tokoh masyarakat itu peduli pada kesehatan keluarga mereka sendiri, dan kita harus bisa berempati terhadap kesulitan mereka. Tantangan dalam pembentukan kesepahaman ini adalah ketidakpedulian daripada tokoh masyarakat dengan strata ekonomi yang lebih tinggi. Sementara itu di kecamatan lainnya dimana para tokoh masyarakatnya memiliki beragam latar belakang, bidan desa setempat merasakan kesulitan dalam membentuk kesepahaman karena setiap tokoh punya pemikiran masing-masing. Namun dengan kesabaran dan ketelatenan akhirnya bisa tercapai kesepahaman seperti yang diharapkan. Dari dua kejadian tersebut, dapat disimpulkan bahwa pembentukan kesepahaman memang bukanlah hal yang mudah, karena selain diperlukan kemampuan komunikasi persuasif, juga bidan desa harus bisa menunjukkan niat baik dan berempati terhadap para tokoh masyarakat 
tersebut, selain itu pula diperlukan kesabaran dan ketelatenan hingga kesepahaman yang diinginkan dapat tercapai dengan baik.

Ketiga, setelah berhasil membentuk kesepahaman secara lisan, maka bidan desa harus melakukan tahap selanjutnya yaitu penetapan dukungan masyarakat, lebih baik secara tertulis misalnya berupa Memorandum of Understanding (MoU) atau paling tidak berbentuk perjanjian tertulis dengan pihak-pihak terkait. Dalam menjalankan perannya seorang Bidan Desa harus mampu melakukan penetapan dukungan masyarakat dan memastikan kesepakatan yang telah dicapai dengan tokohtokoh masyarakat di desa tempat ia ditugaskan. Selain itu seorang bidan desa harus membina hubungan kemitraan dengan dukun beranak (paraji) dan kader Posyandu di desanya. Menurut salah seorang bidan desa awalnya agak sulit untuk menjalin hubungan kemitraan dengan paraji. Dimana bentuk kemitraan itu diantaranya dengan melarang paraji untuk melakukan proses persalinan ibu melahirkan. Apabila paraji mengetahui ada ibu hamil yang mau bersalin, maka harus segera melaporkannya kepada bidan desa, sehingga bidan desa bisa melakukan tindakan persalinan. Disini paraji memiliki peran sebagai asisten bidan desa. Kemudian sebagai pengganti dari penghasilannya yang hilang, maka pemerintah kabupaten Sukabumi memberikan insentif kepada setiap paraji yang melaporkan ibu bersalin sebesar 50 ribu rupiah. Sebaliknya bagi paraji yang sudah masuk program kemitraan, diberlakukan sistem denda apabila diketahui tidak melaporkan adanya persalinan atau menangani sendiri proses persalinan tanpa bantuan bidan. Adapun jumlah dendanya maksimal sebesar insentif yang biasa diterimanya. Sementara itu di kecamatan lain ditemukan adanya tokoh masyarakat yang menyuruh istrinya memeriksakan kehamilan kepada bidan lain di luar wilayah desa maupun kecamatan tempat dia tinggal, dengan alasan sudah merasa cocok dengan bidan yang bersangkutan. Meskipun demikian, bidan desa tetap melakukan pendekatan melalui komunikasi persuasif kepada tokoh masyarakat tersebut, sehingga istrinya mau memeriksakan kehamilannya di bidan desa terdekat dan tidak perlu jauh-jauh hingga ke desa atau kecamatan lain. Dari dua kasus tersebut, tahapan ketiga ini, yaitu penetapan dukungan masyarakat memang menghadapi lebih banyak tantangan karena menyangkut pola pikir dan adat kebiasaan yang sudah berlangsung puluhan tahun, sehingga untuk merubah kebiasaan tersebut diperlukan waktu yang cukup dan dukungan semua pihak.

Keempat, tahapan selanjutnya dalam model komunikasi TTM adalah melaksanakan tahapan penyuluhan dan diseminasi informasi mengenai Kesehatan Ibu dan Anak (KIA) kepada individu di rumah-rumah sasaran, kepada kelompok masyarakat, dan secara massal serta memberikan konseling kepada Ibu Hamil, Ibu Nifas, Ibu Balita, dan Calon Ibu. Salah seorang bidan menyatakan lebih memilih pendekatan personal karena hasilnya lebih efektif, meskipun membutuhkan waktu yang lebih lama, namun pertemuan yang intens terbentuk suatu ikatan yang emosional antara bidan desa dengan pasiennya, bahkan sudah dianggap seperti keluarga sendiri, karena pasiennya percaya bahwa dengan adanya sang bidan desa di sekitar mereka, kesehatan diri dan keluarganya lebih terjaga.

Kelima, salah satu tantangan Bidan Desa dalam memberikan pelayanan adalah masih banyaknya pernikahan dini atau di bawah umur. Di desa nampaknya sudah menjadi hal lumrah jika orangtua menikahkan anaknya yang baru berusia 14 tahun. Padahal secara kesehatan usia tersebut tergolong dengan kehamilan resiko tinggi(resti), apalagi kemudian orangtua tersebut melarang anaknya memeriksakan kehamilan ke bidan desa, maka resiko terjadinya keguguran atau kematian ibu atau bayinya semakin tinggi. Pernikahan dini terjadi karena tingkat pendidikan orangtua dan anaknya yang rendah, dengan taraf ekonomi tidak mampu atau miskin, sehingga salah satu alasan menikahkan anaknya adalah agar tidak lagi menjadi beban keluarga. Dalam menghadapi kasus seperti ini bidan desa bermitra dengan paraji, sehingga paraji dapat memberikan nasehat kepada ibu hamil resiko tinggi dan keluarganya mengenai pentingnya pemeriksaan rutin selama masa kehamilan. Biasanya mereka lebih memperhatikan nasehat dari paraji dan bersedia diperiksa oleh bidan. Sekarang merupakan tugas bidan untuk melakukan komunikasi persuasif kepada pasien tersebut untuk mau bersalin di bidan. Biasanya model komunikasi ini cukup berhasil, namun di sisi lain perlu dukungan penuh dari pejabat desa dan kecamatan setempat untuk memberikan pemahaman kepada seluruh masyarakat mengenai pentingnya kesehatan ibu 
dan anak khususnya selama masa kehamilan, persalinan dan pasca persalinan. Sementara itu di kecamatan lain dengan akses kesehatan yang lebih mudah dan beragam, karena lokasinya merupakan daerah sentra industri, pemahaman mengenai pentingnya mengenai kesehatan ibu hamil dan melahirkan sudah jauh lebih baik. Sebagian besar ibu hamil secara rutin memeriksakan dirinya ke bidan desa terdekat. Kemudian untuk persalinan pun bisa memilih di bidan, rumah bersalin maupun rumah sakit.

Keenam, dalam tahapan yang terakhir, yaitu terpenting dari model TTM adalah melakukan pembinaan menyeluruh, evaluasi, pencatatan dan pelaporan. Pembinaan menyeluruh disini maksudnya bukan hanya dilakasankan oleh bidan desa saja, dan bukan kepada aspek kesehatan saja, namun menyangkut semua aspek seperti dari sisi pendidikan, agama dan kebijakan. Dalam tahap ini bidan desa berbagi tugas dengan Kantor Urusan Agama dan Dinas Pendidikan. KUA misalnya akan menolak untuk menikahkan gadis di bawah umur, sementara dinas pendidikan bertugas untuk mendorong anak usia sekolah menyelesaikan pendidikannya hingga selesai Sekolah Menengah Atas (SMA), sehingga pada saat lulus sudah berusia 18 tahun dan cukup usia untuk menikah. Kemudian dari sisi kebijakan, Bupati Kabupaten Sukabumi mengeluarkan Perda mengenai Kemitraaan Bidan Desa dengan Dukun Beranak (Paraji) dan Kader Posyandu yang diberlakukan secara serentak sejak akhir tahun 2013. Dengan kerjasama yang erat dari semua sektor yang terlibat, Kabupaten Sukabumi telah berhasil menurunkan Angka Kematian Ibu hingga 60\% pada tahun 2014 ini.

\section{SIMPULAN DAN SARAN}

Dari hasil penelitian didapatkan beberapa kesimpulan, yaitu, Pertama, Peran, Tugas dan Fungsi Bidan Desa yang diaplikasikan ke dalam model komunikasi kesehatan Trans Theoretical Model (TTM) dari Prochaska \& Diclemente (1983) menuntut seorang Bidan Desa untuk memiliki kemampuan komunikasi yang handal, khususnya dalam melakukan komunikasi persuasif terhadap individu atau kelompok sasaran. Tujuan dari komunikasi kesehatan oleh bidan desa adalah mengubah perilaku dan kebiasaan individu atau kelompok khususnya dalam lingkup komunikasi Kesehatan Ibu dan
Anak (KIA), dan mencegah mereka untuk kembali kepada kebiasaan lama.

Kedua, dengan kondisi sosial budaya yang sangat beragam di Kecamatan Cikembar, Kecamatan Surade, dan Kecamatan Palabuhanratu, para Bidan Desa dituntut untuk memiliki dedikasi yang tinggi, kesabaran, kejujuran dan kemampuan komunikasi persuasif yang baik dalam menjalankan tugasnya menggunakan model komunikasi kesehatan TTM ini.

Ketiga, Pemerintah Daerah Kabupaten Sukabumi sebagai pemangku kebijakan bersungguh-sungguh untuk menurunkan Angka Kematian Ibu (AKI) melalui berbagai program seperti Jampersal dan Jamkesda, termasuk Program Kemitraan dengan Dukun Beranak (Paraji) dan Kader Posyandu. Penerapan kebijakan ini mulai menunjukkan hasil yang nyata pada akhir tahun 2013, dan terus berlanjut pada tahun 2014 dimana terjadi penurunan Angka Kematian Ibu sebesar 60\%.

Keempat, model komunikasi kesehatan TTM yang dilaksanakan oleh para Bidan Desa di Kabupaten Sukabumi, meskipun dalam pelaksanaannya menemui berbagai hambatan dan tantangan telah memiliki andil yang nyata dalam upaya penurunan Angka Kematian Ibu di Kabupaten Sukabumi sejak akhir tahun 2013 hingga pertengahan tahun 2014.

Upaya penurunan AKI di Indonesia merupakan masalah bersama yang memerlukan komitmen semua pihak untuk dapat mewujudkannya. Pelaksanaan penelitian mengenai model komunikasi kesehatan bidan desa ini merupakan dukungan yang dapat dilakukan peneliti ilmu komunikasi dalam mendukung upaya penurunan AKI di Indonesia. Disarankan untuk melaksanakan penelitian yang lebih komprehensif dalam bidang komunikasi kesehatan dalam upaya mendukung penurunan AKI di Indonesia.

\section{DAFTAR PUSTAKA}

Arikunto, Suharsimi. 2006. Prosedur Penelitian Suatu Pendekatan Praktik. Jakarta: Rineka Cipta.

Azwar, Saifuddin. 2000. Sikap Manusia : Teori dan Pengukurannya. Yogyakarta : Pustaka Pelajar.

Brian Brown, Paul Crawford, Ronald Carter . 2006. Evidence based health communication 
by Brian Brown, McGraw-Hill House, New York.

Cangara, Hafied.(1998). Pengantar Ilmu Komunikasi. Jakarta: Raja Grafindo Persada.

Citrobroto, Suhartin .(1989). Prinsip-Prinsip dan Tehnik Berkomunikasi. Jakarta: Bharata Karya Aksara.

Corcoran, Nova. 2007. Theories and Models in Communicating Health Messages, Sage Publishing, Los Angeles.

Crawford, P., Brown, B. and Nolan, P. (1998) Communicating Care: Language in Health Care Contexts. Cheltenham: Stanley Thornes. Depkes RI. (2007). Modul Surveilans KIA: Peningkatan Kapasitas Agen Perubahan dan Pelaksanaan Program Kesehatan Ibu dan Anak. Dirjen Bina Kesehatan Masyarakat, Jakarta.

Fatimah, Tia, 2013. Profil Ikatan Bidan Indonesia Kabupaten Sukabumi, 2013, Sukabumi.

Graeff. Judith A; John P.Elder; Elizabeth Mills Booth. (1996).edisi Indonesia: Komunikasi untuk Kesehatan dan Perubahan Perilaku (original english edition: Communication for Health and Behaviour Change) Yogyakarta : Gajah Mada University Press

Grant, Charles H. Joy L. Hart and Kandi L. Walker, 2005. Couples, Culture, and Cancer "Journal of Intercultural Communication Studies XIV-3 2005" abstract. East Carolina University University of Louisville

Hovland, Carl. I, Irving L. Janis, and Harold H. Kelley. (1953). Communication and Persuasion: Psychological Studies of Opinion Change. London: Yale University Press.

Infante, Dominic A., Andrew S. Rancer, and Deanna F. Womack. (1990). Building Communication Theory. Illinois: Waveland
Press, Inc.

Kagan, A. (1998) Supported conversation for adults with aphasia: methods and resources for training conversation partners, Aphasiogy, 12: 817-30.

Kemenkes, Profil Kesehatan Nasional 2010, Jakarta

Makowiecka, K, Achadi, E, Izati, Y and Ronsmans, C. 2008, 'Midwifery provision in two districts in Indonesia: how well are rural areas served?', Health Policy and Planning, vol. 23, no. 1, pp. 67-75.

Mueller, Danniel J. 1986. Mengukur Sikapsikap Sosial : Buku Pegangan Bagi Para ahli Riset Dan Pekerja Lapangan. New York : Teachers College Press.

Mulyana, Deddy. 2001 . Metodologi Penelitian Kualitatif: Paradigma Baru Ilmu Komunikasi dan Ilmu Sosial lainnya. Bandung : Remaja Rosdakarya.

Rakhmat, Jalaluddin. 2005. Psikologi Komunikasi. Bandung: Remaja Rosdakarya

Rokx, C, Marzoeki, P, Harimurti, P and Satriawan, E 2009, Indonesia's Doctors, Midwives and Nurses: Current Stock, Increasing Needs, Future Challenges and Options, World Bank, Jakarta.

Sukmawijaya, 2013. Evaluasi Kebijakan Jampersal di Kabupaten Sukabumi, Jakarta.

Thind, A and Banerjee K 2004, 'Home deliveries in Indonesia: who provides assistance?', Journal of Community Health, vol. 29, no. 4, pp. 285-303.

Tones, K and Green, J. 2004. Health promotion: planning and strategies. Sage Publication, London.

WHO, World Health Statistics 2010, World Health Organization, Geneva. 